Pregledni naučni članak

Rad prihvaćen: 6. 6. 2016.
UDK $\quad 005.336 .1: 330.341 .1$

$338: 339.137 .2$

\title{
Relationship Between Competition, Innovation and Productivity Growth
}

\author{
Konstantin Kolev ${ }^{1}$ \\ Maya Tsoklinova ${ }^{2}$
}

\begin{abstract}
This research report analyzes and discusses the relationship between competition, innovation and productivity growth in the long term. Through the study of competition and efficiency the new competitive models in market-oriented industries can be better understood. The special emphasis is placed on evaluating the effectiveness of innovation and the ability to identify the main aspects of obtaining a competitive advantage through innovation activity.
\end{abstract}

Key words: Competition, innovation, efficiency, productivity.

\section{Odnos između konkurencije, inovacija i rasta produktivnosti}

Sažetak: Ovaj rad analizira i razmatra odnos između konkurencije, inovacija i dugoročnog rasta produktivnosti. Kroz proučavanje konkurencije i efikasnosti, mogu se bolje razumeti novi konkurentski model u tržišno orijentisanim industrijama. Poseban akcenat je stavljen na procenu efikasnosti inovacija i sposobnost da se identifikuju glavni aspekti sticanja konkurentske prednost kroz inovativne aktivnosti.

Ključne reči: Konkurencija, inovacije, efikasnost, produktivnost.

\section{Introduction}

The use and application of innovation is a driver of corporate competitiveness. Innovations give real opportunities to a company to distinguish itself among competitors, to integrate new techniques and technologies and be open to interaction with the surrounding environment. As a positive effect on innovation is highlighted their ability to unite and stimulate teams charged with the realization of a project. Thus, personal teamwork skills can be evaluated and ultimately profit from the products of enterprises can be increased. Ever since in $500 \mathrm{BC}$ Heraclitus says that the most constant thing is change i.e. most sustainable competitive advantage is innovation. Therefore, innovation takes utmost strategic importance to the economic nature of the enterprise.

\section{Innovation and competitiveness: essence and relationship}

In a long-term perspective it can be determined that the cost of improving competitiveness can exceed static gains observed in the short term, but also in the long term all the benefits that determine the economic sense of innovation are observed. In the past, organizations have successfully operated when they have solved daily emerging internal problems in their current activity. At the beginning of the XXI century modern economic environment is characterized by incredible dimensions of globalization effects and high rates of development. The latter are carried out in conditions of continuous economic contradictions, uncertainty, chaos, conflict, constant changes in all spheres of public life and fierce competition. Therefore, it is essential that attention should be concentrated not only on the internal

\footnotetext{
1 Лесотехнически университет, 1797, гр. София, бул. Климент Охридски № 10, e-mail: konstantinklv@yahoo.com

Лесотехнически университет, 1797, гр. София, бул. Климент Охридски № 10, e-mail: malenna85@yahoo.com
} 
state of the companies, but also on the choice of long-term and effective business strategies. Since these strategies require to ensure the adaptation of the enterprise to rapidly changing conditions in the external environment. To be competitive, organizations must be distinguished by quick orientation for creation of new products, technologies and qualification of its staff - activities related to promotion of scientific researches. In other words - innovation activity of organizations provide primarily increasing the competitiveness of their products in contemporary conditions.

Competitiveness is a characteristic of the product (service), reflecting its advantage over to this of a competitor, as a degree of compliance to the specific needs of the user and in terms of satisfaction level. Broadly, there are two main elements that determine product competitiveness, namely consumer value and price [1]. The reasons for success and ensuring the competitiveness of the product, there are needed entrepreneurial spirit and innovation, which constitute means of formation and realization of innovation. Product competitiveness can be presented in the following form:

\section{PRODUCT COMPETITIVENESS $=$ QUALITY + PRICE + SERVICES}

Each of the elements of competitiveness is influenced by many factors, and while each of them individually can be seen as a separate unit of government. The goal of each company is to be competitive in the market. The management of competitiveness is related to ensuring the optimal ratio between the above-mentioned elements of which it is composed. This can be achieved by making serious efforts towards increasing product quality, reducing production costs, increasing economies of scale of the enterprise and level of service, the introduction of new innovative technologies. Essentially, modern philosophy to the success of an organization lies in what its interests are subordinated in its entirety on the development, manufacture and supply of competitive products. To achieve this competitiveness it is important to be borne in mind that the first term stands orientation towards customer needs. It implicitly considers the most reliable way of reaching and maintaining high profit. It was there that can detect the interface between competition and innovation. Innovations are the means by which to meet new and higher user requirements. Therefore, it is desirable for any organization to be oriented towards taking innovative actions to address one of the following areas:

$>$ Developing innovative products.

$>$ Orientation toward development of new designs and modifications of existing products.

$>$ Orientation toward manufacturing and supply of traditional products, the main emphasis is on development and use of new techniques and technologies to ensure high quality of market supplied products.

Regardless of which of the above areas will be chosen by the company, it may be concluded that the various expressions of innovation is driven by the driving force of competition. The development of innovation companies is a priority that in many cases enables them to be leaders in the field in which they work. According to one of the classics of economic theory - A. Marshall, entrepreneurship is the engine of the innovation process and is the basis of the market economy. In fact, it creates competition situations requiring the submission of competitive advantages by individual organizations. These advantages are based on an improvement of the overall process of designing and manufacturing of the product to its supply to the consumer [2].

A product may have less, equivalent or greater competitiveness, depending on the extent to which satisfies user needs, compared with similar products offered by competitors' enterprises. This is the ability of a company to beat its competitors and reflects the attractiveness of the offered product, what causes the user to choose it in multitude of available alternatives. Namely this is the possessed characteristics of certain product or properties, which give it superiority over products offered by companies-competitors. In connection with the above, the scientific literature uses the term competitive advantages. Characteristics or properties, that determine comparative advantage, relate not only to the product but also to company that it offers. Competitive advantage is established by comparing the product of a separate entity and therefore is relative. This means that it vary depending 
on whether the comparison is made with the leader sub leader or other enterprises competitor of one or other market. As a result of the competitive struggle of two identical products, market in the face of consumers prefers those who can be bought and can be used flawlessly, interesting and enjoyable. The company can offer such a product that lowers the cost to the buyer in its possession and increases the result of its consumption (increase of acquired utility). In this regard, we refer to economic competitive advantage. It characterizes the overall costs of production and marketing of a product, which monetary expression composes its cost price. These are costs for materials, outside services, amortization, salaries, social security contributions, management and sale of the product. The competitive advantage is achieved through optimization of volume and structure of services, improving internal organization, improving planning, reporting, material and moral incentives [3].

\section{Productivity and efficiency}

Which are the determinants for achieving efficiency in production? This question whose economic and social importance is obvious, affects further questions behind. 50\% of productivity growth in developed countries in the Organization for Economic Cooperation and Development (OECD) over the last half century is due to the introduction of new products and organizational methods (innovation) [4]. Provided that the management of an organization observes the implementation of these recommendations are already in development and implementation of their innovation would lead to success and prosperity not only for the organization but for every one of its employees. Evaluating the effectiveness of innovation (refers to innovation related to product development) is one of the necessary actions recommended by Peter Drucker. The solution to this problem at the organizational level suggests using a system of indicators reflecting the ratio of funds invested in innovation and results. These indicators can be attributed:

$>$ indicators reflecting the estimated return on investment in innovation, as well as indicators of financial performance, taking into account the financial implications of their implementation for the enterprise;

$>$ indicators of economic performance, taking into account the investment and results related to the realization of investments;

$>$ indicators about the social and environmental consequences that relate to investments associated with social activities and environmental protection.

In terms of market relations, an important factor for the growth of the organization is the increase in the volume of production per unit of investment for material and financial resources i.e. increase effectiveness of the organization. This can be achieved through better use of company resources and expanding its manufacturing capabilities based on radical changes in production facilities (introduction of new techniques, technical re-equipment, etc.). The latter are related to investments [5]. An immediate result obtained from investments made in economic terms, for example is modernization and the end result is increased production volume. Therefore, economic efficiency of investment that is made should be regarded as the ratio of the growth in production volume to the volume of capital investment, used to obtain this growth.

To accurately assess the effectiveness of innovation is necessary to specify the financial efficiency, i.e. financial consequences of the implementation of innovation on the one hand the company itself, and on the other - for the municipal and state budgets. Evaluating the effectiveness of innovation is to determine the ratio between their costs and results of their implementation. This evaluation can be based on the following indicators: net income (integral performance); index of profitability; internal rate of return; payback period of investments and others that reflect the specifics of innovation. It is well known that competition leads to increased efficiency, stimulating prices to converge to marginal costs. Increasing the effectiveness of competition is not limited to such static and distribution profits. As pointed out by Liebenstein, which makes contrast between allocative efficiency and so-called "Xefficiency", empirical evidence suggests that the gains that can be achieved only by increasing allocative efficiency are usually extremely small. In an earlier study, for example, the costs of 
misallocation of static resources due to lack of competition in the US are estimated to be much less than one percent of GDP [6].

The return can be described and measured not in terms of productivity and in terms of innovation itself. Businesses whose studies have been successful and have effective and new product processes can improve their competitiveness in a market. Just in this last stage, you can measure the return on innovation, i.e. this part of the research that leads to improved productivity and hence the competitive position of enterprises. Consequently, return on research results in two processes: the first of which is represented by the relationship research, innovation, and the second connection-innovation performance. The model presented in Figure 1 can be considered as deepening the traditional models in which the productivity and hence competitiveness are directly related to R \& D. But this model may be useful only if it is available assessment of innovation or utility of the test results.

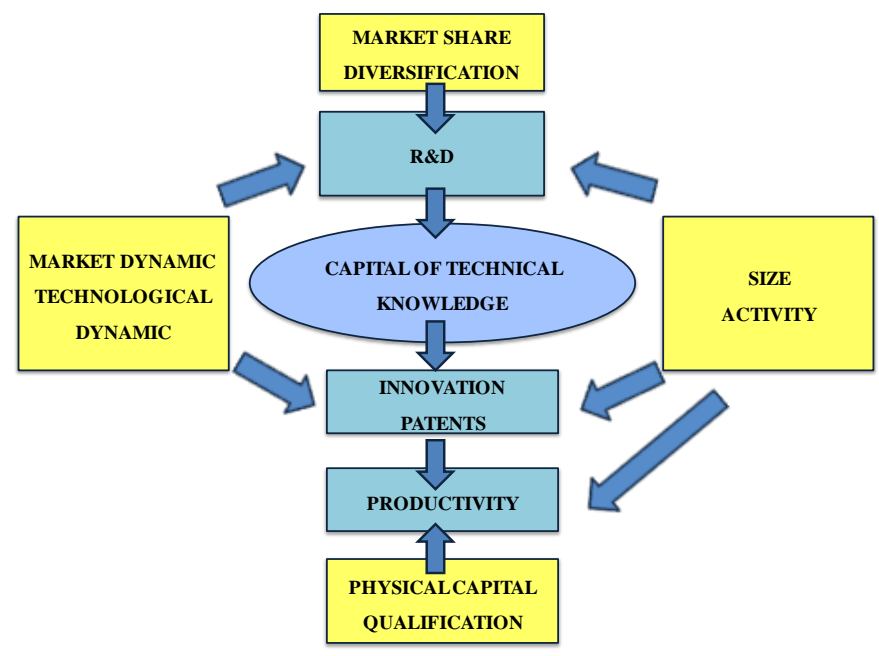

Figure 1. Innovation, competitiveness and productivity

Source: Thoenig, M, Verdier, Th., Innovation défensive et concurrence internationale, Paris, 2003.

The effect of innovation on production is similar to technical progress, which generally occurs in the literature, with the difference that each enterprise has a certain degree of technical progress, which depends on their innovation policy now. Innovation itself is invisible capital source of knowledge obtained as a result of the investments in R \& D. In fact, recent theoretical and empirical research on revenue of competition turning more attention to production efficiency and dynamic efficiency, which can generally be defined in terms of productivity growth through innovation. In short, profits from productive (or technical) efficiency comes from innovation to increase productivity, introduce new and better production methods. Thus, successful innovation ultimately enhance the level and growth rate of productivity in the long run (ie geneirat profits of dynamic efficiency). For example, Spence (1984) examine the relationship between market structure and production performance in terms of both static efficiency of allocation / distribution and the "dynamic technical efficiency.

Our goal is to maximize profits in the long term. To achieve this, the company needs to modernize and invest. Much of the funds for this purpose come from retained earnings. Innovation and investment should provide long-term growth of the company. Competition encourages firms to hold tightly to competitors. This means that they themselves are trying to get bigger to survive. Most company can spend more money on development and introduction of complex products. Consequently, competition does not affect mainly on prices, as stated in neoclassical theory. What the affects competition is the range of products available to customers. Competition in the type concerned sector stimulates investment and technological changes rather than price wars. In the long term allowance as income 
must cover the necessary investments for the company. If the company cannot achieve high enough profitability begin to generate financial difficulties [7].

The objective of profit maximization is based on common sense, when people managing the company are also owners of capital. In any economy there are thousands of companies, but they have a small market share. In modern economies which are dominated by medium and large companies ownership and direct management are separated. From here arise serious problems in relations between the owners (principal) and managers (agents, brokers). While owners are interested in maximizing profits, managers are interested in the benefits they receive. This is the starting point in managerial theories of the firm [8].

To assess the return on innovation is to assess the benefits in terms of productivity of enterprises that cannot fail to develop their $\mathrm{R} \& \mathrm{D}$, which can be done in two ways. The first, is more traditional and uses the number of deposited patents. It remains insufficiently effective because the decision to patent an innovation depends largely on each individual enterprise. The second, more modern, that gives a full and complete assessment of innovation, measures the share of profits from products less than 5 years now. This method has the advantage that it is seen simultaneously and innovation, but also improvements even imitation products. In general, these two methods of assessing innovation help to explain in comparable quantities important benefits of productivity due to research in the field. That's why the second approach makes it possible to more clearly identify the variable effects due to the dynamics of consumer demand and new technologies [9].

\section{Conclusion}

One of the main aspects of the impact of innovation as a factor for achieving competitiveness is based on growth in financial results for that company due to commercialization of innovation. Innovation is the driving force of the market economy. The fiercest global competition today is access to higher technology, new products and services. This is determined by the economic sense of the innovation itself as novelty, providing benefits in technological, consumer or social aspect.

\section{References}

[1] Колев, К., Оценка на конкурентоспособността на горскостопанското предприятие, Наука за гората, кн. 1/2, София, 2014.

[2] El-Nasri, W., Conceptual Model of Strategic Benefits of Competitive Intelligence

Process," International Journal of Business and Commerce, 1(6), 2012, pp. 25-35.

[3] http://www.oecd.org

[4] Pohjola, M. "The New Economy: facts, impacts and policies", Information

Economics and Policy, Vol. 14, 2002, pp. 133-144.

[5] Ahn, S., Competition, Innovation and Productivity Growth: A Review of Theory and Evidence, OECD, 2002.

[6] Ishier, M., What type innovation we need depend on our industry Strategic Management Volume 9, Number 3, 2007 , pp. 211.

[7] Revue Française de Gestion 28, 140, 2002, pp. 89-105.

[8] Накова, Р.,’Повишаване конкурентоспособността чрез маркетингови иновации”, ТУ, София, 2009.

[9] Цоклинова, М., Съвременни измерения на държавната намеса в пазарните отношения: стимулиране на конкурентна среда и икономически растеж, Национална научна конференция на тема „Икономически предизвикателства: растеж, дисбаланси, устойчиво развитие”, на катедра „Икономикс” при УНСС, Издателски комплекс - УНСС, София, ISBN 978-954-644-8347, 2016, стр. 88-95. 